\title{
A novel honey-based product enriched with coumarin from Melilotus flowers
}

\author{
Patrycja Sowa ${ }^{1} \cdot$ Maria Tarapatskyy $^{2} \cdot$ Czesław Puchalski $^{2} \cdot$ Wacław Jarecki ${ }^{3} \cdot$ Małgorzata Dżugan $^{1}(\mathbb{0}$
}

Received: 30 December 2018 / Accepted: 6 March 2019 / Published online: 18 March 2019

(c) The Author(s) 2019

\begin{abstract}
Coumarin is a plant secondary metabolite responsible for the health-promoting properties of the Melilotus officinalis herb used in traditional medicine in the treatment of lymphedema and chronic venous diseases. The aim of this study was to analyze the possibility of honey enrichment with coumarin derived from sweet clover (Melilotus) in two different ways: herb honey and herb-infused honey production. Herb honey was obtained by feeding bees with sugar syrup enriched with a M. officinalis herb water infusion, whereas herbal macerates in multifloral honey were prepared with crushed flowers (fresh and dried) of M. officinalis and Melilotus albus at $20^{\circ} \mathrm{C}$ in dark place for 6 months. Melilotus albus nectar honey $(\mathrm{n}=14)$ was used as control. Using HPLC analysis, the highest content of coumarin (from 41.33 to $137.89 \mathrm{mg} / \mathrm{kg}$ ) and its precursor $o$-coumaric acid (from 6.57 to $25.15 \mathrm{mg} / \mathrm{kg}$ ) in M. officinalis flowers-infused honey were found. Herb honey contains $4.48 \mathrm{mg} / \mathrm{kg}$ coumarin and for the first time, this compound was determined in nectar honey from Polish M. albus honey $(0.05$ to $0.88 \mathrm{mg} / \mathrm{kg}$ ). The addition of Melilotus flowers enhanced antioxidant activity (measured by FRAP, DPPH and PCL methods) of infused-honey in comparison to multifloral honey (control) and herb honey. The coumarin and $o$-coumaric acid were weakly correlated with antioxidant activity. It was found that only herb-infused honey can be proposed as the natural safe remedy for venous diseases prevention.
\end{abstract}

Keywords Melilotus flowers $\cdot$ Herb-infused honey $\cdot$ Herb honey $\cdot$ Coumarin $\cdot$ Antioxidant activity $\cdot$ HPLC

\section{Introduction}

For centuries, the health benefits of honey, as well as herbs, have been known. They were used for the prevention of many diseases. Pro-health properties result from the content of biologically active compounds which include secondary metabolites of plants such as phenolic acids, flavonoids, coumarins, tannins, lignans or terpenoids [1]. In honey, these compounds derived from nectar, pollen, propolis and

Małgorzata Dżugan

mdzugan@ur.edu.pl

1 Department of Chemistry and Food Toxicology, Faculty of Biology and Agriculture, University of Rzeszów, Ćwiklińskiej 1a, 35-601 Rzeszow, Poland

2 Department of Bioenergetics and Food Analysis, Faculty of Biology and Agriculture, University of Rzeszów, Zelwerowicza 4, 35-601 Rzeszow, Poland

3 Department of Crop Production, Faculty of Biology and Agriculture, University of Rzeszów, Zelwerowicza 4, 35-601 Rzeszow, Poland honeydew are used to determine the botanical origin of honey [2].

Thus, intense efforts are made to combine the health benefits of honey and herbs. Numerous new products have appeared on the market, called herb-infused honey, produced by transferring the bioactive compounds of herbs into the honey during infusion [3]. Another popular product is herb honey produced by feeding bees with sugar medium enriched with herbal extract or fruit juices [3-6]. Such products can contain substances which are not presented in floral nectar originating from plant root or leaves and the most recognized are Life mel honey [7]. Herb honey shows stronger health-promoting properties, especially antimicrobial and antioxidant activity compared to nectar honey [3-6].

Melilot honey, also known as sweet clover honey is a commonly known honey variety but rather rarely produced in Poland. This variety is produced by bees from the nectar of two different species of sweet clover: yellow sweet clover (Melilotus officinalis) and white sweet clover (Melilotus albus). It is believed that Melilotus honey contains coumarin compounds, characteristic secondary metabolites found in 
the Melilotus flowers and leaves. However, there are few studies on the chemical composition of Melilot honey, especially in terms of coumarin content [8,9]. In our previous study, for the first time, we proved that Melilotus albus honey exhibits antioxidant and antimicrobial activity [10].

Coumarin is the major compound found in Melilotus species responsible for its characteristic sweet odor and some health-promoting properties, including sedative, spasmolytic, anti-inflammatory, antithrombotic activity. It strengthens the lymphatic vessels, stimulates blood, lymph flows and for that reason is used in the prophylaxis and treatment of lymphedema as well as chronic venous disease (CVD) [11-13]. Synthetic coumarin was used as a flavoring additive for food, alcoholic beverages, and tobacco. Unfortunately, it has been banned based on the results of laboratory tests on rodents where it was shown that coumarin can damage the internal organs (liver, kidneys) and even induce liver and lung cancers [14]. However, the International Agency for Research on Cancer (IARC) qualified coumarin to group III, i.e. compounds that do not show any carcinogenic effect on the human body [15]. Importantly, there is no evidence of coumarin accumulation and its metabolites in living organisms $[14,16]$. Despite this, the European Commission specified a maximum limit for coumarin: $2 \mathrm{mg} / \mathrm{kg}$ in food, with some exceptions of special caramels and alcoholic beverages $(10 \mathrm{mg} / \mathrm{kg})$, cinnamon-containing traditional, seasonal baked goods and chewing gum $(50 \mathrm{mg} / \mathrm{kg})$, breakfast cereals $(20 \mathrm{mg} / \mathrm{kg})$ and other desserts $(5 \mathrm{mg} / \mathrm{kg})$ [17]. In 2004, the European Food Safety Authority (EFSA) recommended a coumarin daily intake limit (TDI) of $0.1 \mathrm{mg} / \mathrm{kg}$ body weight [15].

The aim of the study was to analyze the possibility of fortification honey with coumarin derived from sweet clover (Melilotus) in two different ways: herb honey and herbinfused honey production. Both products obtained were compared with nectar melilot honey in terms of coumarin content and antioxidant activity.

\section{Materials and methods}

\section{Samples}

Fourteen samples of nectar melilot honey, one sample of melilot herb honey and 1 multifloral honey were used. Honey samples from white sweet clover (Melilotus albus) were collected during the years 2013-2017 directly from professional beekeepers localized in different regions of Poland. The botanical origin of the honey samples was confirmed based on pollen analysis according to harmonized methods of melissopalynology [18], and as unifloral samples containing at least $45 \%$ sweet clover, pollen was considered. Herb honey was obtained by feeding bees with sugar syrup (50\% w/v) enriched by M. officinalis herb (10\% water infusion solution). Multifloral fresh honey obtained in 2015 from the ecological apiary, was used to produce infused-herb honey. Then, 8 equal samples ( $100 \mathrm{~g}$ each) of multifloral honey were mixed with fresh or dried crushed flowers of Melilotus officinalis and Melilotus albus and macerated at $20{ }^{\circ} \mathrm{C}$ in a dark place for 6 months. Two different doses of the Melilotus flowers were used for fresh $5 \%$ and $2.5 \% \mathrm{w} / \mathrm{w}$ and for dried $1.8 \%$ and $0.9 \% \mathrm{w} / \mathrm{w}$ (corresponding to the addition of fresh flowers taking into account mean water content 65\%). Melilotus flowers were collected in July 2015 in natural populations at flowering stage and dried at room temperature in the dark (to $4 \% \mathrm{w} / \mathrm{w}$ moisture). The moisture content was determined by a moisture analyzer (MA 50.R Radwag).

\section{HPLC analysis}

\section{Chemicals and standards}

Coumarin (>99\%), o-coumaric acid (97\%), methanol, acetonitrile, ammonium acetate, acetic acid, hydrochloric acid were purchased from Sigma-Aldrich (St. Louis, USA). All chemicals were of analytical grade. Ultrapure $\mathrm{H}_{2} \mathrm{O}$ was obtained from the deionizer HLP 5 (Hydrolab, Poland).

\section{Samples preparation}

Thirty gram of honey samples were diluted in $100 \mathrm{ml}$ of ultrapure water acidified with $\mathrm{HCl}$ solution to $\mathrm{pH} 2$. The solutions obtained were filtered using Sep-Pak C18 cartridges (Waters, Ireland), in a few steps: rising cartridges with $10 \mathrm{ml}$ of methanol, $10 \mathrm{ml}$ of acidified ultrapure prepared honey solutions, again $10 \mathrm{ml}$ of acidified water and finally eluted with $10 \mathrm{ml}$ methanol into a flask. In the next step, the solution obtained was concentrated on a rotary evaporator and the dry residue was dissolved in $2 \mathrm{ml}$ of $50 \%(\mathrm{v} / \mathrm{v})$ acetonitrile. All extractions were done in two repetitions.

Flowers were ground in a laboratory mill (A11 IKA, Germany) to obtain a homogenous drug powder. $1 \mathrm{~g}$ of drug material was mixed with $20 \mathrm{ml}$ of boiling water and sonicated in a sonication bath for $30 \mathrm{~min}$ at room temperature (U-504 Ultron, Moorpark, USA) and then centrifuged for $10 \mathrm{~min}$ at $3500 \mathrm{rpm}$ (MPW-260, Warsaw, Poland). The supernatant was filtered through a $0.20 \mu \mathrm{m}$ syringe nylon filter (Merck Millipore, Darmstadt, Germany).

\section{Instrumentation and chromatographic conditions}

Analyses were performed on a SYKAM S600 (Ersing, Germany) system equipped with a binary gradient pump, a column thermostat, a degasser and a photodiode array detector (PDA). The analytical column Bionacom Velocity STR C18 
$(3.0 \times 100 \mathrm{~mm}, 2.5 \mu \mathrm{m})$ thermostatted at $40{ }^{\circ} \mathrm{C}$ was used for chromatographic separations. The mobile phase $(0.5 \mathrm{ml} /$ $\mathrm{min}$ ) consisted of $5 \mathrm{mM}$ ammonium acetate, $0.2 \%(\mathrm{v} / \mathrm{v})$ acetic acid in water (phase $\mathrm{A}$ ) and acetonitrile/methanol (1:2 $\mathrm{v} / \mathrm{v}$ ) (phase B). The samples were eluted by the following gradient $70 \%$ A (2 min), 35\% A (13 min), and again $70 \%$ A $(5 \mathrm{~min})$. The injected volume was $20 \mu \mathrm{l}$. The chromatograms were recorded at $280 \mathrm{~nm}$ and the identification of coumarin and $o$-coumaric acid were achieved by comparing their retention time values with those of standards. Accuracy was checked by spiking samples with a solution containing each standard compound. Quantitative determination of the considered compounds in the extracts was performed using external standards by means of six points calibration curve ranging from 0.01 to $10 \mu \mathrm{g} / \mathrm{ml}\left(\mathrm{r}^{2} \geq 0.9989\right)$. Average standard errors for the peak areas of replicate injection were lower than $5 \%$, which shows good repeatability of the calibration curve. Determined LOD was $0.03 \mu \mathrm{g} / \mathrm{ml}$, LOQ $0.05 \mu \mathrm{g} / \mathrm{ml}$ for coumarin and for o-coumaric acid $0.04 \mu \mathrm{g} /$ $\mathrm{ml}$ and $0.09 \mu \mathrm{g} / \mathrm{ml}$ respectively.

\section{Antioxidant activity and total phenolic content}

The antioxidant activity of the samples tested was measured as DPPH (radicals scavenging activity) and FRAP assay (reducing power) according to procedures described in our previous paper Dżugan et al. [3]. Total phenolic content (TPC) was also determined using procedure contained in Dżugan et al. [3]. The radicals scavenging activity was expressed as the percentage of DPPH discoloration (\% of inhibition), reducing power as $\mu \mathrm{mol}$ Trolox-TE equivalents per kilogram of product ( $\mu \mathrm{M} \mathrm{TE} / \mathrm{kg}$ of honey product) and total phenolic content as $\mathrm{mg}$ of gallic acid equivalents per kilogram of product (mg GAE/ $\mathrm{kg}$ of honey product), respectively.

\section{Antioxidant capacity PCL assay}

Antioxidant activity was determined by photochemiluminescence (PCL) using the Photochem ${ }^{\circledR}$ instrument (AG, Jena, Germany). The activity of the hydrophilic (PCL-ACW) and the hydrophobic (PCL-ACL) antioxidant fractions were determined according to the procedures provided by the manufacturer's instruction. The results were expressed as mmol ascorbic acid equivalents-AA per kilogram of product $(\mathrm{mM} / \mathrm{kg})$ in PCL-ACW and as mmol Trolox-TE equivalents per kilogram of product $(\mathrm{mM} / \mathrm{kg})$ in PCL-ACL. The study was performed using commercial reagent kit ACW and ACL (Analytik Jena AG, Jena, Germany). Honey solutions $(10 \mathrm{mg} / \mathrm{ml})$ using water for $\mathrm{ACW}$ and methanol for ACL were prepared. The analysis of the results was carried out using PCLSoft 5.1 software.

\section{Statistical analysis}

The results are presented as the mean values with standard deviations (SD). The significant differences $(\mathrm{p}<0.05)$ between the analyzed samples in terms of coumarin and $o$-coumaric acid were determined using one-way analysis of variance (ANOVA) with Tukey's test. Differences in the antioxidant activity of herb-infused honey and herb honey in comparison to multifloral honey (control) as well as in comparison to melilot nectar honey were tested by ANOVA using Dunnett's test $(\mathrm{p}<0.05)$. The correlation between the analyzed parameters was calculated using Pearson's correlation test. All calculations were performed using StatSoft Statistica 10.0 software (StatSoft, Inc., Tulsa, OK).

\section{Results and discussion}

\section{Coumarin content in studied honey products}

The coumarin levels in nectar melilot honey, herb honey, and herb-infused honey were completely different (Table 1). Generally, the coumarin content in studied honey samples decreased in the order: multifloral honey enriched with $M$. officinalis flowers $>$ multifloral honey enriched with $M$. albus flowers $>$ M. officinalis herb honey $>$ nectar $M$. albus honey.

The content of coumarin in fortified honey depended on the dose of herb, its species and slightly on the dryness of the herb. The highest content of coumarin was found in honey with $5 \%$ w/w fresh $M$. officinalis flowers addition $(137.89 \mathrm{mg} / \mathrm{kg})$, the lowest in nectar sweet clover honey (average value $0.33 \mathrm{mg} / \mathrm{kg}$ ). All samples differed with statistical significance, excluding the higher addition of $M$. officinalis, in both fresh and dried form. However, the product containing fresh flowers of both Melilotus species showed a tendency to fermentation during storage (the observation was carried out after the measurements). Due to the slight differences in the level of coumarin in herb-infused honey for fresh and dried flowers. the use of dried herbs is preferable.

Samples fortified with $M$. officinalis herb contain about $20 \%$ more coumarin than in the case of $M$. albus herb. The same tendency for extracts of dried flowers of both plant species was found (Table 1). It has been assumed that white sweet clover contains less coumarin, but literature data show that plants belonging to the Melilotus genus are extremely diverse in terms of the content of this compound [19-21]. In the present study, we found that the higher content of coumarin in the dry $M$. officinalis flowers contributed a higher amount of this compound in M. officinalis-infused honey.

Baroni et al. [9] considered coumarin to be a specific marker of white sweet clover honey. The content of this compound was measured using HS-SPME-GC-MS and 
Table 1 The coumarin and o-coumaric acid content in studied honey samples

\begin{tabular}{|c|c|c|}
\hline Samples & Coumarin $(\mathrm{mg} / \mathrm{kg})$ & $o$-Coumaric acid $(\mathrm{mg} / \mathrm{kg})$ \\
\hline M.albus nectar honey $(\mathrm{n}=14)$ & $0.33 \pm 0.02^{\mathrm{a}}$ & n.d \\
\hline Min-max & $0.05-0.88$ & \\
\hline M. officinalis herb honey $(\mathrm{n}=1)$ & $4.48 \pm 0.02^{\mathrm{b}}$ & $0.42 \pm 0.03^{\mathrm{a}}$ \\
\hline \multicolumn{3}{|l|}{ M. officinalis-infused honey } \\
\hline \multicolumn{3}{|l|}{ Fresh flowers } \\
\hline $5 \% \mathrm{w} / \mathrm{w}$ & $137.89 \pm 0.29^{c}$ & $25.15 \pm 0.05^{\mathrm{b}}$ \\
\hline $2.5 \% \mathrm{w} / \mathrm{w}$ & $41.33 \pm 0.10^{\mathrm{d}}$ & $6.57 \pm 0.38^{c}$ \\
\hline \multicolumn{3}{|l|}{ Dried flowers } \\
\hline $1.8 \% \mathrm{w} / \mathrm{w}$ & $136.59 \pm 0.17^{\mathrm{c}}$ & $21.55 \pm 0.05^{\mathrm{d}}$ \\
\hline $0.8 \% \mathrm{w} / \mathrm{w}$ & $88.39 \pm 0.25^{\mathrm{e}}$ & $12.56 \pm 0.45^{\mathrm{e}}$ \\
\hline \multicolumn{3}{|l|}{ M. albus-infused honey } \\
\hline \multicolumn{3}{|l|}{ Fresh flowers } \\
\hline $5 \% \mathrm{w} / \mathrm{w}$ & $118.14 \pm 0.54^{\mathrm{f}}$ & $15.54 \pm 0.23^{\mathrm{f}}$ \\
\hline $2.5 \% \mathrm{w} / \mathrm{w}$ & $34.55 \pm 0.06^{\mathrm{g}}$ & $4.07 \pm 0.94^{\mathrm{g}}$ \\
\hline \multicolumn{3}{|l|}{ Dried flowers } \\
\hline $1.8 \% \mathrm{w} / \mathrm{w}$ & $111.41 \pm 0.74^{\mathrm{h}}$ & $11.62 \pm 0.59^{\mathrm{e}}$ \\
\hline $0.9 \% \mathrm{w} / \mathrm{w}$ & $61.49 \pm 0.74^{\mathrm{i}}$ & $5.75 \pm 0.06^{\mathrm{c}, \mathrm{g}}$ \\
\hline Multifloral honey (control sample) & n.d & n.d \\
\hline M. officinalis dried flowers & $8873.85 \pm 0.18$ & $825.88 \pm 0.02$ \\
\hline M. albus dried flowers & $6356.07 \pm 0.07$ & $279.71 \pm 0.06$ \\
\hline
\end{tabular}

The results for all tested samples are reported as the mean value \pm standard deviation $(n=2)$, except nectar melilot honey where the mean value of 14 tested samples and the minimum and maximum value were presented

a,b,c,d,e,f,g,h,i Represent significant differences between tested honey products $(\mathrm{p}<0.05)$ ranged out $4.99 \mathrm{mg} / \mathrm{kg}$. Our results obtained by HPLC method for Polish sweet clover honey samples contain less coumarin from 0.05 to $0.88 \mathrm{mg} / \mathrm{kg}$. Jasicka-Misiak et al. based on GC-MS analysis [8] concluded that fresh sweet clover honey obtained from M. officinalis, does not contain coumarin, but its presence was observed in stored honey (average concentration was $0.59 \mathrm{mg} / \mathrm{kg}$ ). Meanwhile, we have identified this compound in fresh honey. Hence, we conclude that the content of coumarin in sweet clover honey depends rather on its quality, but we did not carry out storage tests for our honey samples.

Analyzing the HPLC chromatograms obtained (not shown) no other derivatives of coumarin were observed, excluding $o$-coumaric acid considered to be a precursor of coumarin [22]. As expected, o-coumaric acid was found in the highest concentration depending on the herb dose used (from 4.07 to $25.15 \mathrm{mg} / \mathrm{kg}$ ). Statistically significant differences $(p<0.05)$ depended on the dose and species of flowers used were observed (almost twofold higher concentration for $M$. officinalis herb). The efficiency of extraction was slightly dependent on the form of flowers used (fresh or dried). The o-coumaric acid content was highly correlated with the coumarin concentration $(r=0.97)$ as a consequence of metabolite-pathway. Although coumarin is a well-known compound, its biosynthetic mechanism based on the expression of specific genes has been clarified recently [22].

\section{Antioxidant activity of studied honey products}

The antioxidant properties of the products tested (Table 2) were evaluated with different methods (FRAP and DPPH standard tests as well as rarely used very sensitive photochemiluminescence method-PCL) [23]. Moreover, total phenolic content (TPC) was measured (Table 2). Generally, $M$. officinalis-infused honey exhibits higher antioxidant activity in all used tests and also contained a higher amount of phenolic compounds compared to multifloral honey (control sample) as well as $M$. officinalis herb honey. A higher dose of flowers caused significantly higher values of antioxidant activity (by $45 \%$ and 55\% for M. albus and M. officinalis flowers, respectively) (Fig. 1). At the same time, the coumarin content multiplied by 110- and 136-fold for M. albus and $M$. officinalis, respectively (Fig. 1.) However, the increase of antioxidant activity of Melilotus-infused honey was lower (ranged from $48.21 \%$ to $36.46 \%$ in DPPH test) than observed in our previous study for other herb-infused honey (between 24.07 to $100 \%$ depending on the type of plant used) [3]. In turn, samples of nectar honey from white sweet clover showed a very large variation in the parameters examined, which was 
Table 2 Radical scavenging activity (DPPH), reducing/antioxidant power (FRAP), antioxidant capacity (PCL-ACW, PCL-ACL), ACW/ACL ratio and total phenolic content (TPC) of the studied honey samples

\begin{tabular}{|c|c|c|c|c|c|c|}
\hline Samples & $\mathrm{DPPH}(\%)$ & FRAP (mM TE/kg) & $\begin{array}{l}\text { PCL-ACW (mM AA/ } \\
\mathrm{kg})\end{array}$ & $\begin{array}{l}\text { PCL-ACL (mM TE/ } \\
\mathrm{kg} \text { ) }\end{array}$ & ACW/ACL & TPC (mg GAE/kg) \\
\hline \multicolumn{7}{|c|}{ M. albus nectar honey } \\
\hline$(n=14)$ & $42.66 \pm 14.24^{\mathrm{a}}$ & $1885.80 \pm 612.69^{\mathrm{a}}$ & $9.06 \pm 2.00^{\mathrm{a}}$ & $0.78 \pm 0.17^{\mathrm{a}}$ & 11.61 & $510.36 \pm 108.44^{\mathrm{a}}$ \\
\hline Min-max & $27.38-55.88$ & $1033.30-3231.18$ & $6.16-13.55$ & $0.61-1.21$ & $9.05-14.19$ & $345.51-715.52$ \\
\hline $\begin{array}{l}\text { M. officinalis herb } \\
\text { honey }(\mathrm{n}=1)\end{array}$ & $32.65 \pm 0.11^{\mathrm{b}, \mathrm{A}}$ & $1200.00 \pm 1.02^{\mathrm{b}, \mathrm{B}}$ & $4.84 \pm 0.12^{\mathrm{b}, \mathrm{A}}$ & $0.70 \pm 0.28^{\mathrm{a}, \mathrm{A}}$ & 6.91 & $263.11 \pm 0.31^{\mathrm{b}, \mathrm{B}}$ \\
\hline \multicolumn{7}{|c|}{ M. officinalis-infused honey } \\
\hline \multicolumn{7}{|l|}{ Fresh flowers } \\
\hline $5 \% \mathrm{w} / \mathrm{w}$ & $44.12 \pm 0.62^{\mathrm{a}, \mathrm{B}}$ & $2515.42 \pm 1.22^{\mathrm{b}, \mathrm{B}}$ & $8.10 \pm 0.01^{\mathrm{b}, \mathrm{B}}$ & $1.10 \pm 0.05^{\mathrm{b}, \mathrm{B}}$ & 7.36 & $484.72 \pm 0.53^{\mathrm{b}, \mathrm{B}}$ \\
\hline $2.5 \% \mathrm{w} / \mathrm{w}$ & $40.77 \pm 0.84^{\mathrm{a}, \mathrm{A}}$ & $2176.90 \pm 0.50^{\mathrm{b}, \mathrm{B}}$ & $6.63 \pm 0.18^{\mathrm{b}, \mathrm{B}}$ & $0.85 \pm 0.06^{\mathrm{a}, \mathrm{B}}$ & 7.80 & $406.30 \pm 1.44^{\mathrm{b}, \mathrm{B}}$ \\
\hline \multicolumn{7}{|l|}{ Dried flowers } \\
\hline $1.8 \% \mathrm{w} / \mathrm{w}$ & $48.21 \pm 2.31^{\mathrm{a}, \mathrm{B}}$ & $2551.93 \pm 0.47^{\mathrm{b}, \mathrm{B}}$ & $8.60 \pm 0.39^{\mathrm{a}, \mathrm{B}}$ & $0.94 \pm 0.01^{\mathrm{b}, \mathrm{B}}$ & 9.15 & $524.35 \pm 0.16^{\mathrm{b}, \mathrm{B}}$ \\
\hline $0.9 \% \mathrm{w} / \mathrm{w}$ & $41.82 \pm 1.68^{\mathrm{a}, \mathrm{A}}$ & $2196.24 \pm 0.17^{\mathrm{b}, \mathrm{B}}$ & $7.66 \pm 0.16^{\mathrm{b}, \mathrm{B}}$ & $0.87 \pm 0.02^{\mathrm{a}, \mathrm{B}}$ & 8.80 & $441.42 \pm 0.37^{\mathrm{b}, \mathrm{B}}$ \\
\hline \multicolumn{7}{|c|}{ M. albus-infused honey } \\
\hline \multicolumn{7}{|l|}{ Fresh flowers } \\
\hline $5 \% \mathrm{w} / \mathrm{w}$ & $40.63 \pm 1.36^{\mathrm{a}, \mathrm{A}}$ & $2400.03 \pm 0.15^{\mathrm{b}, \mathrm{B}}$ & $7.63 \pm 0.36^{\mathrm{b}, \mathrm{B}}$ & $0.75 \pm 0.01^{\mathrm{a}, \mathrm{A}}$ & 10.17 & $492.81 \pm 0.74^{\mathrm{b}, \mathrm{B}}$ \\
\hline $2.5 \% \mathrm{w} / \mathrm{w}$ & $36.46 \pm 2.54^{\mathrm{b}, \mathrm{A}}$ & $2305.87 \pm 1.08^{\mathrm{b}, \mathrm{B}}$ & $5.52 \pm 0.39^{\mathrm{b}, \mathrm{A}}$ & $0.74 \pm 0.01^{\mathrm{a}, \mathrm{A}}$ & 7.46 & $439.63 \pm 0.49^{\mathrm{b}, \mathrm{B}}$ \\
\hline \multicolumn{7}{|l|}{ Dried flowers } \\
\hline $1.8 \% \mathrm{w} / \mathrm{w}$ & $46.06 \pm 0.35^{\mathrm{a}, \mathrm{B}}$ & $2465.49 \pm 0.32^{\mathrm{b}, \mathrm{B}}$ & $7.57 \pm 0.04^{\mathrm{b}, \mathrm{B}}$ & $0.90 \pm 0.02^{\mathrm{b}, \mathrm{B}}$ & 8.41 & $493.74 \pm 0.11^{\mathrm{b}, \mathrm{B}}$ \\
\hline $0.9 \% \mathrm{w} / \mathrm{w}$ & $39.43 \pm 1.15^{\mathrm{a}, \mathrm{A}}$ & $2334.61 \pm 1.08^{\mathrm{b}, \mathrm{B}}$ & $6.45 \pm 0.19^{\mathrm{b}, \mathrm{B}}$ & $0.83 \pm 0.04^{\mathrm{a}, \mathrm{B}}$ & 7.77 & $443.22 \pm 0.29^{\mathrm{b}, \mathrm{B}}$ \\
\hline $\begin{array}{l}\text { Multifloral honey } \\
\text { (control sample) }\end{array}$ & $34.30 \pm 0.86^{\mathrm{A}}$ & $1990.46 \pm 0.13^{\mathrm{A}}$ & $5.17 \pm 0.34^{\mathrm{A}}$ & $0.63 \pm 0.01^{\mathrm{A}}$ & 8.21 & $330.60 \pm 0.66^{\mathrm{A}}$ \\
\hline
\end{tabular}

The results for all tested samples are reported as the mean value \pm standard deviation $(\mathrm{n}=2)$, except for M. albus nectar honey where the average value of all tested samples and the minimum and maximum value were presented

$T E$ Trolox equivalents, $A A$ ascorbic acid equivalents, $G A E$ gallic acid equivalents

${ }^{\mathrm{a}, \mathrm{b}}$ Significant differences between nectar M. albus honey and other product; ${ }^{\mathrm{A}, \mathrm{B}}$ Between multifloral honey and other product $(\mathrm{p}<0.05)$

Fig. 1 The efficiency of multifloral honey enrichment in antioxidant and coumarin in comparison to nectar melilot honey in two obtained products: herb honey and herb-infused honey (for higher dried herb dose used $5 \% \mathrm{w} / \mathrm{v}$ )

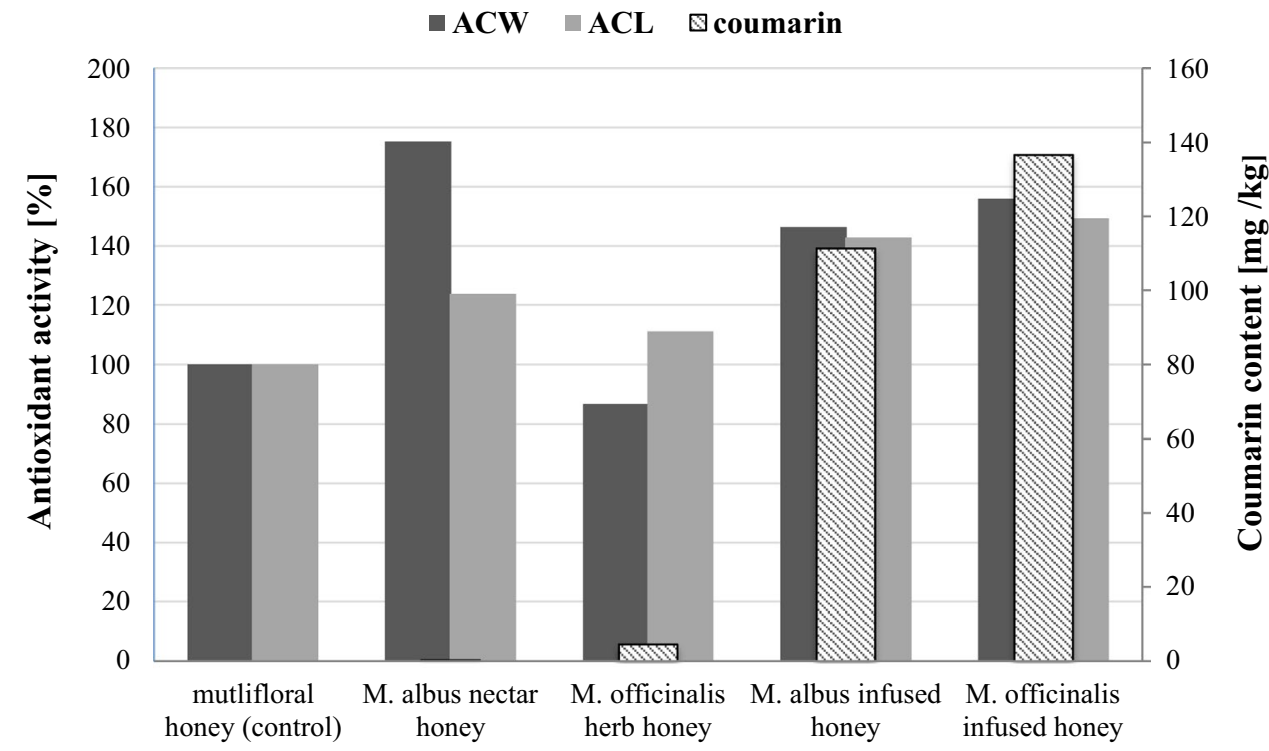

also observed in our previous study [10]. However, the antiradical activity of $M$. albus honey (42.66\% of inhibition on average) was lower than observed by Jasicka-Misiak et al. [8] for yellow sweet clover honey (55.96\%). In this study, we found that nectar M.albus honey was richer in antioxidants as well as coumarins than both herb honey and multifloral honey. 
The highest phenolic content was determined for $M$. officinalis-infused honey with a higher dose of dried flowers (524.35 mg GAE/kg) the lowest for M. officinalis- infused honey with a smaller dose of fresh flowers (406.30 mg GAE/ $\mathrm{kg}$ ). Based on the results, enrichment does not depend on the Melilotus species, but mainly on the amount of additive. However, no such differentiation was obtained as in the research Stajner et al. [24], where acacia honey was enriched by Rosa spp. fruit. Antioxidant activity by the PCL photochemiluminescence method for other varietal honey was determined for the first time in our previous research [23, 25]. This method allows the differentiation of antioxidant activity to both types of antioxidant: water soluble (ACW kit) and lipid-soluble (ACL kit). The activity of hydrophilic antioxidants ranged from $8.60 \mathrm{mmol} \mathrm{AA} / \mathrm{kg}$ (5\% addition of dried M. officinalis) to $5.52 \mathrm{mmol} \mathrm{AA} / \mathrm{kg}$ (2.5\% addition of fresh M. albus) and only the sample with the lowest activity did not differ statistically significantly compared to the control. A slightly greater variation was observed based on analysis of lipid-soluble antioxidant fraction. The results obtained for enriched honey ranging between 1.10 and $0.74 \mathrm{mmol} \mathrm{TE} / \mathrm{kg}$ (fresh 5\% M. officinalis, fresh $2.5 \%$ M. albus, respectively). The ratio between ACW and ACL fractions for melilot honey was established as an average 11.61, which is lower than the value obtained for other nectar honey, from 20 for dandelion to 34 for rape honey, respectively [25]. This suggested a specific antioxidant profile of this honey where a phase of hydrophilic antioxidant is higher than in other nectar honey.

A strong positive correlation (all over 0.7 ) between antioxidant activities measured by different methods was found which is consistent with our previous research on the antioxidant activity of honey products [3, 10, 23, 25]. The coumarin content was not significantly correlated with antioxidant activity (coumarin vs FRAP $r=0.45$; vs. DPPH $r=0.09$; vs. TPC $r=0.004$; PCL-ACW $r=0.16$; vs. PCLACL $r=0.40$ ) which may suggest that it is not active agent during the method used.

\section{Safe consumption of the studied honey products}

Due to the much higher content of coumarin found in Melilotus-infused honey as well as inconclusive scientific reports regarding coumarin toxicity the safety of obtaining products should be considered. Assuming an overall limit of coumarin content in foods $(2 \mathrm{mg} / \mathrm{kg})$ it should be stated that only nectar melilot honey meets the required standard. The level of coumarin in herb honey and herb-infused honey was ten times and even 100 times higher. These products would require separate legal regulations which will establish a higher limit as in the case of some cinnamon products, e.g. chewing gum $(50 \mathrm{mg} /$ $\mathrm{kg}$ ). Considering a tolerable daily intake (TDI) $0.1 \mathrm{mg}$ coumarin per kg body weight daily intake of this compound for an adult man (70 kg of weight) amounts $7 \mathrm{mg}$ per day. Such a dose cannot be consumed with nectar honey or herb honey, but it can be taken with $50 \mathrm{~g}$ (four teaspoons of infused honey). As honey is a high-calorie product (about $330 \mathrm{kcal} / 100 \mathrm{~g}$ ) it can be an taken in controlled doses not exceeding 60-100 g daily [26]. Assuming that a safe intake of honey at the level of $100 \mathrm{~g}$ (which provides $330 \mathrm{kcal}$ ) the coumarin intake amounts 0.03, 0.4 and $13.7 \mathrm{mg}$ for nectar honey, herb honey and herbinfused honey, respectively. Medical coumarin used in a dose of 90-400 mg per day (often as standardized M. officinalis extract) in the treatment of lymphedema and chronic venous insufficiency is reported in clinical trials [27-31]. This suggests that herb-infused honey can be considered to be natural medicine and could be used in the treatment of existing diseases. Meanwhile, nectar honey and herb honey are effective agents in venous diseases prevention. Due to the varying content of coumarin in the plant, the level of coumarin in herbinfused honey should be controlled and its strict dosage should be established.

\section{Conclusion}

The results clearly indicate the possibility of effective fortification of honey with coumarin by prolonged macerating Melilotus flowers into with higher efficiency than during melilot herb honey production. Better results for M. officinalis than M. albus dried flowers were obtained. Maceration of flowers in honey enhanced its antioxidants, but an incomparably higher value of coumarin concentration increase was observed. The weak correlation between antioxidant activity and the coumarin content indicates that coumarin is not the main component determining the antioxidative activity of Melilotus enriched honey. In conclusion fortification of honey by Melilotus plants gives a new product with therapeutic potential in treatment and prevention of lymphedema and chronic venous disease.

\section{Compliance with ethical standards}

Conflict of interest The authors declare that they have no conflict of interest.

Open Access This article is distributed under the terms of the Creative Commons Attribution 4.0 International License (http://creativeco mmons.org/licenses/by/4.0/), which permits unrestricted use, distribution, and reproduction in any medium, provided you give appropriate credit to the original author(s) and the source, provide a link to the Creative Commons license, and indicate if changes were made.

\section{References}

1. M. Wink, Medicines. (2015). https://doi.org/10.3390/medicines2 030251 
2. T. Istasse, N. Jacquet, T. Berchem, E. Haubruge, B.K. Nguyen, A. Richel, Anal Chem Insights. (2016). https://doi.org/10.4137/ACI. S39739

3. M. Dżugan, P. Sowa, M. Kwaśniewska, M. Wesołowska, M. Czernicka, Plant Foods Hum. Nutr. (2017). https://doi.org/10.1007/ s11130-016-0593-y

4. R. Socha, L. Juszczak, S. Pietrzyk, T. Fortuna, Food Chem. (2009). https://doi.org/10.1016/j.foodchem.2008.08.029

5. V.A. Isadorov, R. Bagan, I. Swiecicka, Food Chem. (2015). https ://doi.org/10.1016/j.foodchem.2014.08.112

6. M. Lukasiewicz, S. Kowalski, M. Makarewicz, LWT Food Sci Technol. (2015). https://doi.org/10.1016/j.lwt.2015.06.029

7. J. Zidan, L. Shetver, A. Gershuny, A. Abzah, S. Tamam, M. Stein, E. Friedman, Med. Oncol. (2006). https://doi.org/10.1385/ MO:23:4:549

8. I. Jasicka-Misiak, E. Makowicz, N. Stanek, Molecules (2017). https://doi.org/10.3390/molecules22010138

9. M.V. Baroni, M.L. Nores, P. Diaz Mdel, G.A. Chiabrando, J.P. Fassano, C. Costa, D.A. Wunderlin, J. Agric. Food Chem. (2006). https://doi.org/10.1021/jf061080e

10. P. Sowa, D. Grabek-Lejko, M. Wesołowska, S. Swacha, M. Dżugan, Lett Appl Microbiol. (2017). https://doi.org/10.1111/ lam.12749

11. K.N. Venugopala, V. Rashmi, B. Odhav, Biomed Res Int. (2013). https://doi.org/10.1155/2013/963248

12. T. Kubrak, R. Podgórski, M. Stompor, Eur J Clin Exp Med. (2017). https://doi.org/10.15584/ejcem.2017.2.12

13. M. Perrin, A.A. Ramelet, Eur. J. Vasc. Endovasc. Surg. (2011). https://doi.org/10.1016/j.ejvs.2010.09.025

14. K. Abraham, F. Wohrlin, O. Lindtner, G. Heinemeyer, A. Lampen, Mol. Nutr. Food Res. (2010). https://doi.org/10.1002/mnfr.20090 0281

15. C. Sproll, W. Ruge, C. Andlauer, R. Godelmann, D.W. Lachenmeier, Food Chem. (2008). https://doi.org/10.1016/j.foodc hem.2007.12.068

16. S.P. Felter, J.D. Vassallo, B.D. Carlton, G.P. Daston, Food Chem. Toxicol. (2006). https://doi.org/10.1016/j.fct.2005.08.019

17. (E.C.) Regulation, no $1334 / 2008$ of the European Parliament and of the Council of 16 December 2008 on flavorings and certain food ingredients with flavoring properties for use in and on foods and amending Council Regulation (EEC) No 1601/91, Offical Journal of the European Communities, L354: 34-50
18. W. Von Der Ohe, L. Persano Oddo, M.L. Piana, M. Morlot, P. Martin, Apidologie. (2004). https://doi.org/10.1051/apido:20040 50

19. M.R. Abbasi, S. Hosseini, L. Pourakbar, Crop Sci. Biotech. (2017). https://doi.org/10.1007/s12892-016-0038-0

20. J.L. Kitchen, D. Mclachln, S. Hughes, D.K. Revell, Anim Prod Aust. (2002). http://www.asap.asn.au/livestocklibrary/2002/kitch en1C.pdf

21. R.M. Nair, A. Whittall, S.J. Hughes, A.D. Craig, S.M. Miller, T. Powell, G.C. Auricht, New Zeal J Agr Res. (2010). https://doi. org/10.1080/00288233.2010.495743

22. K. Luo, F. Wu, D. Zhang, R. Dong, Z. Fan, R. Zhang, Z. Yan, Y. Wang, J. Zhang, Sci Rep. (2017). https://doi.org/10.1038/s4159 8-017-04111-y

23. M. Wesołowska, M. Dżugan, Food Anal. Method. (2017). https:// doi.org/10.1007/s12161-016-0715-z

24. D. Stajner, B.M. Popović, J. Canadanović-Brunet, S. Dilas, G. Ćetković, LWT Food Sci. Technol. (2014). https://doi. org/10.1016/j.lwt.2013.08.025

25. M. Dżugan, M. Tomczyk, P. Sowa, D. Grabek-Lejko, Molecules. (2018). https://doi.org/10.3390/molecules23082069

26. B. Kędzia, E. Hołderna-Kędzia, Post Fitoter 4, 213 (2006)

27. J.R. Casley-Smith, R.G. Morgan, N.B. Piller, N. Engl. J. Med. (1993). https://doi.org/10.1056/NEJM199310143291604

28. J.R. Casley-Smith, M. Boris, S. Weindorf, B. Lasinski, Cancer. 83, 843 (1998)

29. A.L. Moseley, C.J. Carat, N.B. Piller, Ann. Oncol. (2007). https ://doi.org/10.1093/annonc/mdl182

30. G. Pastura, M. Mesiti, M. Saitta, D. Romeo, N. Settineri, R. Maisano, M. Petix, A. Giudice, Clin. Ter. 150, 403 (1999)

31. W. Vanscheid, E. Rabe, B. Naser-Hijazi, A.A. Ramelet, H. Partsch, C. Diehm, U. Schultz-Ehrenburg, F. Spengel, M. Wirsching, V. Götz, J. Schnitker, H.H. Henneicke-von Zeppelin, Vasa. (2002). https://doi.org/10.1024/0301-1526.31.3.185

Publisher's Note Springer Nature remains neutral with regard to jurisdictional claims in published maps and institutional affiliations. 